\title{
An Opportunistic Pathogen Afforded Ample Opportunities: Middle East Respiratory Syndrome Coronavirus
}

\author{
Ian M. Mackay ${ }^{1,2, *}$ (D) and Katherine E. Arden ${ }^{2}$ \\ 1 Public and Environmental Health Virology, Forensic and Scientific Services, Department of Health, \\ Queensland Government, Coopers Plains, 4108 QLD, Australia \\ 2 Child Health Research Centre, The University of Queensland, South Brisbane, 4101 QLD, Australia; \\ k.arden@uq.edu.au \\ * Correspondence: ian.mackay@uq.edu.au
}

Received: 14 November 2017; Accepted: 1 December 2017; Published: 2 December 2017

\begin{abstract}
The human coronaviruses (CoV) include HCoV-229E, HCoV-OC43, HCoV-NL63, and HCoV-HKU1, some of which have been known for decades. The severe acute respiratory syndrome (SARS) CoV briefly emerged into the human population but was controlled. In 2012, another novel severely human pathogenic CoV—-the Middle East Respiratory Syndrome (MERS)-CoV—was identified in the Kingdom of Saudi Arabia; $80 \%$ of over 2000 human cases have been recorded over five years. Targeted research remains key to developing control strategies for MERS-CoV, a cause of mild illness in its camel reservoir. A new therapeutic toolbox being developed in response to MERS is also teaching us more about how CoVs cause disease. Travel-related cases continue to challenge the world's surveillance and response capabilities, and more data are needed to understand unexplained primary transmission. Signs of genetic change have been recorded, but it remains unclear whether there is any impact on clinical disease. How camels came to carry the virus remains academic to the control of MERS. To date, human-to-human transmission has been inefficient, but virus surveillance, characterisation, and reporting are key to responding to any future change. MERS-CoV is not currently a pandemic threat; it is spread mainly with the aid of human habit and error.
\end{abstract}

Keywords: Middle East respiratory syndrome; MERS; coronavirus; comorbidity; infection; camel; zoonosis; emerging virus

\section{Introduction}

Acute respiratory tract infections (ARTIs) are a frequent cause of morbidity and mortality and a common reason for both outpatient visits and hospitalisations. Among humans worldwide, RNA viruses the agents that cause ARTI most frequently-usually a self-limiting upper respiratory tract syndrome. Coronaviruses ( $\mathrm{CoVs}$ ) are recombining, enveloped viruses with long positive-sense RNA genomes. They are ancestrally zoonotic in origin, having adapted to bind a diverse range of cellular receptors [1]. Four human coronaviruses (HCoVs) have evolved, initially from bats, camelids, and rodents, to become distinct global, endemic, seasonal pathogens causing mild to moderate ARTI among humans $[2,3]$.

The HCoVs occupy two of four genera in the subfamily Coronavirinae [4]. Human coronavirus 229E and Betacoronavirus-1 subspecies $\mathrm{HCoV}$-OC43 have been known for more than 50 years, while Human coronavirus NL63 and Human coronavirus HKU1 were first characterised in 2004 and 2005, respectively.

A Severe acute respiratory syndrome-related coronavirus (SARS-CoV) briefly emerged into the human population during 2002-2004 but was controlled and is not known to circulate today. Its brief but severe emergence sparked renewed study of CoVs. In 2012, another novel, severely pathogenic CoV was 
identified in the Kingdom of Saudi Arabia (KSA); 80\% of over 2000 human cases have been recorded over five years [5]. Both SARS-CoV and the new Middle East respiratory syndrome coronavirus (MERS-CoV; belonging to the species Middle East respiratory syndrome-related coronavirus) evolved from ancestral, but different, bat CoVs. Travel history and laboratory analysis would be required to differentiate MERS from SARS, if it still occurred [6]. To date, most MERS cases have been limited to countries in the Arabian Peninsula with rare travel-related spillovers. One case precipitated a large healthcare multi-facility outbreak in the Republic of Korea in 2015.

A confirmed case of MERS occurs when a person, irrespective of signs or symptoms, has a laboratory-reported MERS-CoV infection. A probable case requires a minimum of a clinically diagnosed acute febrile disease, an epidemiologic link, and a partial laboratory diagnostic profile [7].

We briefly review recent literature and the current understanding of MERS and MERS-CoV highlighting some knowledge gaps.

\section{Virus Attachment}

The viral receptor for MERS-CoV is a transmembrane glycoprotein called dipeptidyl peptidase- 4 (DPP-4), which has a wide tissue distribution in humans, including on alveolar cells of the lower respiratory tract and in the small intestine [8,9]. DPP-4 interacts with the MERS-CoV at its receptor-binding domain (RBD) within the spike fusion protein (Figure 1). DPP-4 expression is upregulated in the lower respiratory tract of those with poor lung function, in the lower respiratory tract of those with untreated asthma, and in soluble form in the plasma of obese patients [8,10-12]. Whether blood borne DPP-4 interferes with MERS-CoV or, through reversible binding, contributes to its systemic distribution of MERS-CoV during serious disease, are questions worthy of further investigation. Studies of the upper respiratory tract have found little to no sign of DPP-4 expression levels or tissue distribution, although one study identified DPP-4 enzymatic activity, suggesting it is present $[10,13,14]$. It may be useful to expand the search for DPP-4 expression to tissues indicated by cases with different disease states. Co-infections, especially with viruses known to inflame the lower respiratory tract and trigger asthma exacerbations such as rhinoviruses are also of interest. MERS-CoV may also use sialic acids as a low-affinity but selective cellular receptor to aid attachment and entry into DPP-4 positive cells [15]. 

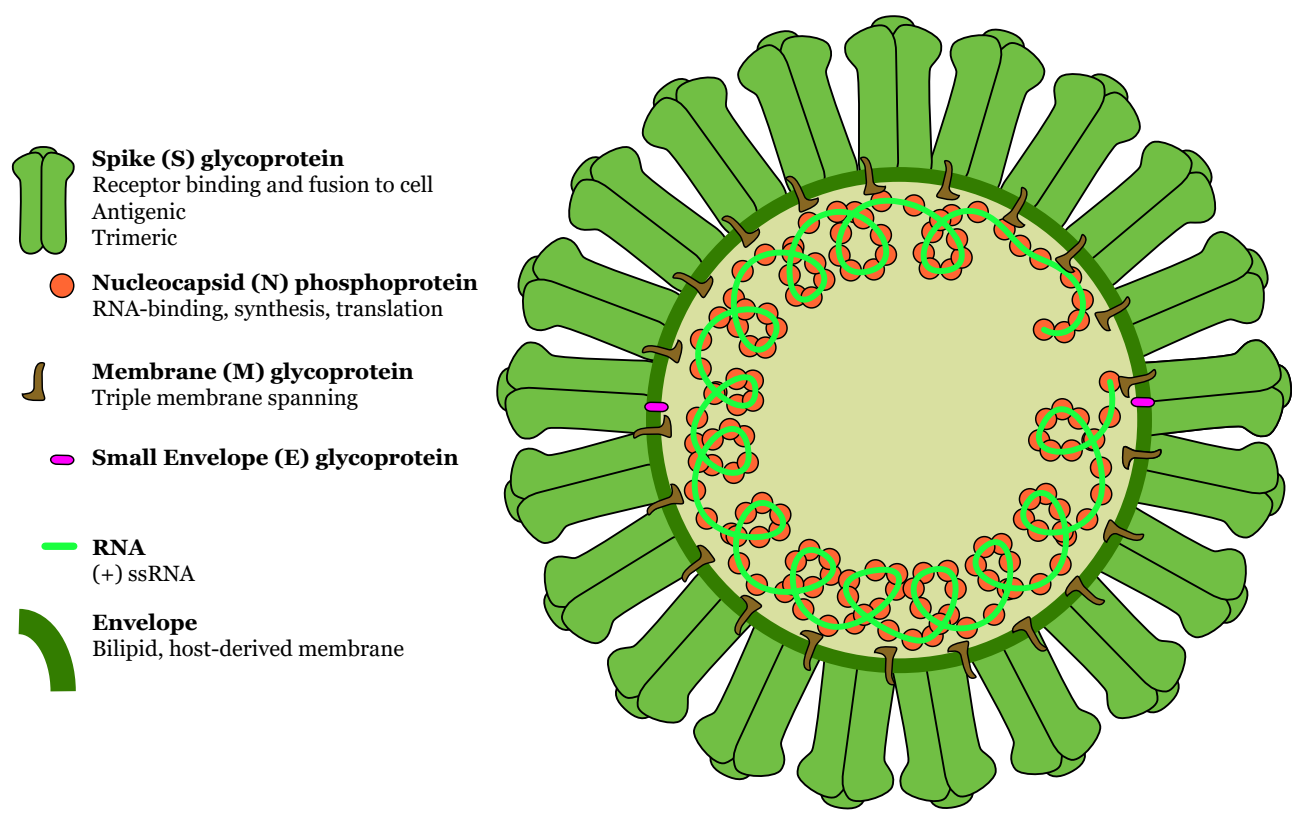

Figure 1. Schematic of a predicted MERS-CoV virion. Along with membrane and envelope transmembrane proteins, the spike glycoprotein protrudes from a host cell-derived lipid bilayer, giving the virion a distinctive appearance. Positive-sense viral RNA is associated with nucleocapsid phosphoprotein in a helical structure. DOI:10.6084/m9.figshare.5639320.

\section{Disease and Immunity}

MERS is most well characterised as a respiratory disease of humans. Extensive inflammation and immune evasion are hallmarks of severe disease ascribed to CoVs [16,17]. Among confirmed MERS cases, fever, cough, and dyspnoea are the most common clinical manifestations [18,19]. The mean incubation period for MERS is between 2 and 13 days. Longer periods are associated with a reduced risk of death [20-22]. MERS-CoV infection also results in mild and subclinical outcomes.

The typical MERS case is a Saudi male aged between 21 and 60 years, often presenting to a hospital with pneumonia, or worse $[18,23,24]$. Severe MERS occurs most frequently among those with comorbidities including diabetes mellitus, cirrhosis, and others affecting respiratory, renal, and cardiac systems $[23,25,26]$. Downregulation of innate immune response mediators associated with some of these disorders may be related to the severity of MERS [27]. It may be that the high frequency of severe MERS reflects elevated prevalence of certain comorbidities in the Middle East region [27]. Comorbidities did not feature among SARS cases, as they have among cases of MERS; MERS-CoV is a highly opportunistic pathogen.

In June 2015, an outbreak in the Republic of Korea found confirmed cases presented with fever, cough, and upper respiratory tract signs and symptoms, progressing within a week to lower respiratory tract distress with lymphopenia and elevated liver enzymes $[23,24,27,28]$. MERS can progress to acute respiratory distress syndrome and multiorgan system failure requiring intensive supportive care $[23,24,29]$. Extra pulmonary infection does occur, likely resulting from haematogenous transport of virus, which is an area in need of further study [9,30]. Similarly, little is known about sequelae following MERS-CoV infection; in one study, those who survived acute respiratory distress syndrome were well one year later [19]. Another study identified delayed neurological manifestations during treatment of MERS cases, but lacked long-term follow-up [31].

Death occurs among $30-40 \%$ of MERS cases; approximately $40 \%$ of cases in the KSA, and $20 \%$ of cases in the Republic of Korea, where mortality ranged from $7 \%$ among younger age groups to $40 \%$ among those aged 60 years and above. Among studies of fatal cases, death occurred between 5-15 days 
after symptom onset $[18,21,32,33]$. Because the extent of subclinical or mild infections in the community remains unquantified, mortality figures may be overestimates [34].

MERS-CoV variants exist as a single antigenic group in lineage $C$ of the genus Betacoronavirus $[35,36]$. When MERS-CoV infection is subclinical or less severe, humoral immune responses may be weak, delayed, short-lived, or undetectable [37-41]. Humans can still be reinfected if they have pre-existing neutralising antibodies, similarly to what is seen in camels [41]. However, survivors of symptomatic MERS do develop antibodies, including neutralising antibodies, which decline but persist for 1-3 years [37,42]. Whether these antibodies prevent future infection remains to be examined. Those with mild or subclinical MERS still develop $\mathrm{CD} 8^{+} \mathrm{T}$-cell responses, and survivors of more severe MERS, including those who do not mount an antibody response, develop both $\mathrm{CD} 8^{+}$and $\mathrm{CD} 4^{+} \mathrm{T}$-cell responses [43].

\section{Detection Methods and Gaps}

Robust laboratory-based real-time RT-PCR diagnostic tools were described immediately after MERS-CoV was discovered and remain reliable [44]. Several different research-based antibody detection protocols have also been reported for human and animal studies [45]. Molecular and serological kits are commercially available [46]. While current molecular methods are rapid, there are many steps that combine to delay publication of a final test result; from the initial decision to request a MERS-CoV test, to sample collection, nucleic acid extraction, PCR, additional sampling, repeat testing, and reporting processes. Molecular, rapid, and sensitive point-of-care tests (POCTs) are not available but would help support infection control in healthcare settings.

The World Health Organisation recommends testing of appropriate samples for MERS-CoV RNA using real-time RT-PCR methods with subgenomic sequencing to confirm screening results, as necessary [47]. Repeat testing is often required [17,48]. Virus isolation by culture is not a recommended tool. Detecting antibodies against MERS-CoV may be useful to identify a seroconversion that can define a probable case when confirmation by RT-PCR has been unsuccessful or impossible [47].

Mild and subclinical MERS cases are reported among younger people including healthcare workers and children $[17,49,50]$. It remains unclear what proportion of MERS-CoV infections are truly subclinical after one study found many were initially incorrectly classified [51]. Difficulty identifying a useful diagnostic antibody response in mild and subclinical disease means seroprevalence studies likely under-report the history of MERS-CoV [40]; MERS-CoV specific $\mathrm{CD}^{+}$testing may be helpful [43]. The usefulness of serology needs clarification.

\section{Virus Origins: Camel to Human with a Bat Ancestry}

Humans are incidental hosts of MERS-CoV. The principal natural reservoir host of MERS-CoV is the dromedary camel [16]. Among camels, MERS-CoV infection manifests in a manner similar to that in which the common cold manifests in humans. The camel upper respiratory tract expresses high levels of the DPP-4 receptor [13]. The study of MERS-CoV highlights the need for collaboration between politics and diverse basic and applied fields of research at the human-animal interface-a One Health approach. Camel trade plays a central role in the movement of infected hosts around the Arabian Peninsula. Pakistan and North, West, and East Africa all harbour MERS-CoV-infected camels [52-55]. Alpacas, llamas, and pigs are potential hosts according to experimental evidence [56-58]. In addition, alpacas have been found to be naturally infected [59].

The virus genetically detected or biologically cultured from humans is nearly identical to that isolated from camels and, in some instances, has been used to identify transmission routes. Signs of virus change have appeared with continued surveillance over time. Recombination has been identified, and variation in the region of the tropism-defining spike protein in a divergent Egyptian camel MERS-CoV variant [60] has been associated with reduced infectivity in vitro, compared to human and less divergent camel MERS-CoV variants [61]. Nearly 300 human and animal MERS-CoV genome sequences have been produced from MERS-CoV infections since 2012, but few studies 
of the functional impact of identified mutations have been conducted. Among MERS-related coronaviruses [62], there may now exist three conspecific viruses: the camel MERS-CoV and the bat CoVs, BtVs-BetaCoV/SC2013 [63] and PREDICT/PDF-2180 [64], each with related but distinct genomes and divergent spike genes. Ongoing viral surveillance and characterisation is essential to ensure variants with increased efficiency in attachment, fusion, or replication do not emerge unnoticed. Surveillance of human respiratory illness in MERS-CoV-positive camel countries outside of the Arabian Peninsula is currently lacking [52].

\section{Transmission: Known Unknowns}

According to the KSA Ministry of Health [65], nearly half of all MERS cases are classified as primary cases: zoonoses originating from direct or indirect contact with infected dromedary camels, or from an unidentified source which had no link to any other (known) human case. The precise mechanism by which MERS-CoV spreads from camels to humans is unknown but is not essential for enacting precautions to reduce exposure to infected animals. Secondary cases make up slightly more than half of all MERS cases, mostly resulting from exposure associated with a healthcare facility.

Infectious MERS-CoV is presumed to be found in droplets [59] but modelling has also suggested the possibility of airborne spread [45]. Virus remains viable for at least $48 \mathrm{~h}$ on plastic and steel surfaces, presumably underpinning the extensive contamination of air and surfaces in hospitals housing patients with MERS [66-71]. The virus appears sensitive to standard heat and chemical inactivation measures [72,73].

Antibodies to MERS-CoV have been found in camel sera as far back as 1983. In each animal, antibodies to MERS-CoV are short-lived and do not prevent reinfection [52,74,75].

Human contact with camels is often associated with the collection, preparation, and ingestion of camel milk or meat. Female camels, especially those bred for milking, have the highest rates of MERS-CoV seropositivity; MERS-CoV RNA has been detected in milk from one study and virus was found to be stable after being spiked into milk samples from another study [53,76,77]. Camels in larger herds have higher rates of seropositivity compared with smaller herds [52,53]. Female and young camels also have higher rates of MERS-CoV RNA than older and male camels [53]. While no evidence for human infection resulting from ingestion has been presented, it has been found that experimentally inoculated human intestinal cells and organoids can host productive MERS-CoV infection and that MERS-CoV can remain infectious after transit through gastric acids [9]. Further, intestinal, respiratory, and neurological infection follows intragastric inoculation of DPP-4 transgenic mice [9]. Whether camel milk and meat actually contain a suitable infectious dose to cause intestinal infection of humans is yet to be determined [78]. It seems likely that the processes of milking and butchery may contaminate surfaces and generate infectious droplets that include sufficient inoculum from which a human infection could result via inhalation or self-inoculation. It is not known whether the eyes act as a portal for MERS-CoV entry.

Since the majority of human-to-human MERS-CoV infections are associated with healthcare, improved infection control and prevention is considered key for preventing outbreaks among humans not at occupational risk of exposure to infected animals [79]. In the outbreak in the Republic of Korea, 5 of 186 cases were responsible for $83 \%$ of transmission events; most new cases did not result in any identified onward transmission; the reproduction $\left(R_{0}\right)$ number was calculated as 3.9 and 1.9-6.9 from selected KSA outbreaks [80]. Three of these five cases were coughing; prolonged exposures, crowding, and large numbers of contacts were important factors for disproportionate virus transmission [81-83].

The role, if any, for mild or subclinical MERS-CoV infections in maintaining the virus in the human population has not been convincingly addressed. A healthcare worker found to shed viral RNA for more than five weeks in the absence of disease adds urgency to the need for such studies [84]. None among 82 contacts of a mildly symptomatic MERS-CoV-infected healthcare worker seroconverted, but there was no mention of whether the index case seroconverted [85]. In a KSA hospital outbreak investigation, contacts of subclinical MERS-CoV-infected healthcare workers became RT-PCR positive, suggesting 
transmission was a possibility [17]. Some studies report very rare camel contact among human cases and no history of contact with other MERS-CoV-infected humans, and this raises the question of how these primary cases acquire infection [18]. Community spread and subclinical transmission need more attention.

The Hajj pilgrimage, an annual mass gathering in the KSA, provides many opportunities for MERS-CoV to transmit and then spread globally. However, it is rhinoviruses, influenza viruses, and other seasonal respiratory viruses that have, to date, driven the bulk of respiratory disease associated with the Hajj. This indirectly reinforces that MERS-CoV does not transmit efficiently among humans outdoors [86]. In hospital environments, healthcare workers and other patients and carers who experience prolonged exposure to infectious cases, in the absence of suitable personal protective equipment (PPE), are those who usually become infected. There have been examples of the 20/80 rule, whereby relatively few infected individuals are responsible for a disproportionate number of new cases [83]. Insufficient cleaning of room surfaces, inadequate room ventilation, and overcrowding have also been suggested to drive indoor MERS-CoV transmission.

\section{Prevention and Treatment}

No specific antiviral or licensed vaccine is available for a $\mathrm{CoV}$ that infects humans, but a range of candidates exist. Even if MERS-CoV infection is rare, transmits poorly, and does not evolve to become a pandemic threat, it serves in a useful role to drive vaccine research of other CoVs, both current and yet to emerge. For cases in healthcare facilities, improving hand hygiene, the use of PPE (gloves, gown, respiratory, and eye protection [87]), and surface cleaning can help disrupt transmission, as can rapid triage of febrile patients with respiratory signs and symptoms. To prevent MERS-CoV infection from dromedary camels, precautions include avoiding contact with camel nasal secretions, cooking camel meat, and pasteurising camel milk until further studies better quantify the risk attached to each of these potential pathways.

Vaccines to prevent $\mathrm{CoV}$ disease require both humoral and cellular immunity [88]. Because airway immune responses may be key to preventing the establishment of human MERS-CoV infection, localised deposition of an aerosolised vaccine could prove useful [88]. A number of vaccine platforms and payloads have proceeded although progress has been challenged by the need for animal models that suitably reconstitute human lower respiratory tract disease to show evidence of any preventative effect $[89,90]$. Some candidates have progressed to clinical trials [91,92]. The spike protein and RBD elicit neutralising antibody responses and have been employed as the payload for a number of platforms [88,93,94] including DNA vaccines [95], modified vaccinia virus Ankara [96,97], measles virus [97-100], and human- [26,101] and chimpanzee-adenovirus-based vectors [99]. There are also Venezuelan equine encephalitis replicons expressing nucleocapsid [101], nanoparticles [102], and structural and non-structural deletion mutants of MERS-CoV [103].

Vaccination of camels is likely to be the most rapid, least expensive, and best intervention for preventing rare spillovers that then become amplified by humans in healthcare settings. Successes have been reported, but the approach is challenged by the problem that camels are naturally reinfectable with MERS-CoV, even in the presence of a high titre of neutralising antibodies [52,74,104]. To date, camel vaccines reduce viral load but do not prevent virus shedding [104,105]. Human vaccines could target the occupational at-risk groups, which include healthcare, farm, barn, market, and slaughterhouse workers $[56,88,106]$. More widespread application of a MERS vaccine at this time does not seem warranted.

The rarity of seropositive donors, sometimes low antibody titres, and a lack of clinical evidence have made the use of convalescent sera from recovering MERS patients a possibility for treatment, but one with significant limitations [39]. Instead, human monoclonal antibodies targeting the RBD and polyclonal antibodies may provide treatment options for those at risk of severe outcomes [107-110]. Clinical trials are awaited. 
Early control of viral replication is important and administration of interferon (IFN) $\beta 1 \mathrm{~b}$ or a ribavirin and IFN $\alpha 2 b$ combination within hours initially showed promise. Their practical use in humans is challenging because, if not infected while in a healthcare setting, humans usually present for care with well advanced disease $[111,112]$. Combined treatments which reduce viral replication and the host immune response to it are likely to be valuable developments [16].

A wide range of repurposed or novel potential antivirals including polymerase, nucleotide synthesis and protease inhibitors, and fusion-inhibiting peptides [66,91,113-117] have been investigated [91,115]. Corticosteroid use is not recommended for acute respiratory distress syndrome [113]. Comparative studies and randomised controlled trials are mostly lacking [91].

\section{Future Considerations}

Though much is already known, it remains important to clarify the routes of human infection, including the role of the eyes in contracting infection, among primary human cases. The development of rapid molecular POCT tests and alternatives to serology, such as CD8 ${ }^{+}$detection can help us understand MERS-CoV transmission, which can lead to reductions in outbreaks. The scale of mild and subclinical cases among non-hospitalised Arabian Peninsula communities is unknown, as is their role in transmission. Most knowledge of MERS comes from studies of hospital-based populations or linked community contacts. Future prospective long-term cohort studies of mild community respiratory illnesses using molecular methods would be useful. Children have so far been largely absent from the MERS case tally, but they may represent an important population for prospective study. Recent lessons from the Zika and Ebola viruses should also inform new studies seeking possible long-term sequelae and viral persistence and highlight the need to follow-up severe MERS patients.

\section{Conclusions}

In September 2017, MERS-CoV passed its fifth year since discovery. It remains a rare cause of disease in a geographically defined region of the world known for the concurrent presence of infected camel hosts. Much of what we know about MERS relates to severe disease. Travel-related cases continue to challenge the rest of the world's surveillance and response capabilities, and we need more data to understand unexplained primary transmission. Signs of genetic change in MERS-CoV have been recorded, but it remains unclear whether they change clinical disease. How camels came to carry the virus they live with today remains unknown, but it is academic for the control of MERS. To date, human-to-human transmission has been inefficient, but virus surveillance and characterisation will ensure any change to the status quo is identified. MERS-CoV is not currently a pandemic threat; it is spread with the aid of human habit and error. Nevertheless, a much needed therapeutic toolbox is being developed, and in this process we are learning more about how CoVs cause disease, how they confound our immune responses, where they come from, and how to prevent and treat their respiratory infections [90]. Focused research is needed to minimise the impact of MERS, basing control strategies on evidence gleaned from specifically addressing relevant unknowns.

Acknowledgments: Our thanks to Victor Corman for advice on aspects of this review.

Conflicts of Interest: The authors declare no conflict of interest.

\section{References}

1. Hulswit, R.J.; de Haan, C.A.; Bosch, B.J. Coronavirus spike protein and tropism changes. Adv. Virus Res. 2016, 96, 29-57. [CrossRef] [PubMed]

2. Channappanavar, R.; Perlman, S. Pathogenic human coronavirus infections: Causes and consequences of cytokine storm and immunopathology. Semin. Immunopathol. 2017, 39, 529-539. [CrossRef] [PubMed]

3. Forni, D.; Cagliani, R.; Clerici, M.; Sironi, M. Molecular evolution of human coronavirus genomes. Trends Microbiol. 2017, 25, 35-48. [CrossRef] [PubMed] 
4. (ICTV) ICoToV. Taxonomic Information. Available online: https://talk.ictvonline.org/taxonomy/ (accessed on 10 October 2017).

5. Mackay, I.M.; Arden, K.E. Middle East respiratory syndrome: An emerging coronavirus infection tracked by the crowd. Virus Res. 2015, 202, 60-88. [CrossRef] [PubMed]

6. Gao, H.; Yao, H.; Yang, S.; Li, L. From SARS to MERS: Evidence and speculation. Front Med. 2016, 10, 377-382. [CrossRef] [PubMed]

7. WHO. Middle East respiratory syndrome coronavirus: Case definition for reporting to WHO: World Health Organization. 2017. Available online: http://www.who.int/csr/disease/coronavirus_infections/case_ definition/en/ (accessed on 8 August 2017).

8. Seys, L.J.M.; Widagdo, W.; Verhamme, F.M.; Kleinjan, A.; Janssens, W.; Joos, G.F.; Bracke, K.R.; Haagmans, B.L.; Brusselle, G.G. DPP4, the MERS coronavirus receptor, is upregulated in lungs of smokers and COPD patients. Clin. Infect. Dis. 2017. [CrossRef] [PubMed]

9. Zhou, J.; Li, C.; Zhao, G.; Chu, H.; Wang, D.; Yan, H.H.; Poon, V.K.; Wen, L.; Wong, B.H.; Zhao, X.; et al. Human intestinal tract serves as an alternative infection route for Middle East respiratory syndrome coronavirus. Sci. Adv. 2017, 3, eaao4966. [CrossRef] [PubMed]

10. Meyerholz, D.K.; Lambertz, A.M.; McCray, P.B., Jr. Dipeptidyl peptidase 4 distribution in the Human respiratory tract: Implications for the Middle East respiratory syndrome. Am. J. Pathol. 2016, 186, 78-86. [CrossRef] [PubMed]

11. Stengel, A.; Goebel-Stengel, A.; Teuffel, P.; Hofmann, T.; Busse, P.; Kobelt, P.; Rose, M.; Klapp, B.F. Obese patients have higher circulating protein levels of dipeptidyl peptidase IV. Peptides 2014, 61, 75-82. [CrossRef] [PubMed]

12. Shiobara, T.; Chibana, K.; Watanabe, T.; Arai, R.; Horigane, Y.; Nakamura, Y.; Hayashi, Y.; Shimizu, Y.; Takemasa, A.; Ishii, Y. Dipeptidyl peptidase-4 is highly expressed in bronchial epithelial cells of untreated asthma and it increases cell proliferation along with fibronectin production in airway constitutive cells. Respir. Res. 2016, 17, 28. [CrossRef] [PubMed]

13. Widagdo, W.; Raj, V.S.; Schipper, D.; Kolijn, K.; van Leenders, G.J.; Bosch, B.J.; Bensaid, A.; Segales, J.; Baumgartner, W.; Osterhaus, A.D.; et al. Differential expression of the Middle East respiratory syndrome coronavirus receptor in the upper respiratory tracts of humans and dromedary camels. J. Virol. 2016, 90, 4838-4842. [CrossRef] [PubMed]

14. Grouzmann, E.; Monod, M.; Landis, B.; Wilk, S.; Brakch, N.; Nicoucar, K.; Giger, R.; Malis, D.; Szalay-Quinodoz, I.; Cavadas, C.; et al. Loss of dipeptidylpeptidase IV activity in chronic rhinosinusitis contributes to the neurogenic inflammation induced by substance $P$ in the nasal mucosa. FASEB J. 2002, 16, 1132-1134. [CrossRef] [PubMed]

15. Li, W.; Hulswit, R.J.G.; Widjaja, I.; Raj, V.S.; McBride, R.; Peng, W.; Widagdo, W.; Tortorici, M.A.; van Dieren, B.; Lang, Y.; et al. Identification of sialic acid-binding function for the Middle East respiratory syndrome coronavirus spike glycoprotein. Proc. Natl. Acad. Sci. USA 2017. [CrossRef] [PubMed]

16. De Wit, E.; van Doremalen, N.; Falzarano, D.; Munster, V.J. SARS and MERS: Recent insights into emerging coronaviruses. Nat. Rev. Microbiol. 2016, 14, 523-534. [CrossRef] [PubMed]

17. Alfaraj, S.H.; Al-Tawfiq, J.A.; Altuwaijri, T.A.; Alanazi, M.; Alzahrani, N.; Memish, Z.A. Middle East respiratory syndrome coronavirus transmission among health care workers: Implication for infection control. Am. J. Infect. Control 2017. [CrossRef] [PubMed]

18. Aleanizy, F.S.; Mohmed, N.; Alqahtani, F.Y.; El Hadi Mohamed, R.A. Outbreak of Middle East respiratory syndrome coronavirus in Saudi Arabia: A retrospective study. BMC Infect. Dis. 2017, 17, 23. [CrossRef] [PubMed]

19. Khalid, I.; Alraddadi, B.M.; Dairi, Y.; Khalid, T.J.; Kadri, M.; Alshukairi, A.N.; Qushmaq, I.A. Acute management and long-term survival among subjects with severe Middle East respiratory syndrome coronavirus pneumonia and ARDS. Respir. Care 2016, 61, 340-348. [CrossRef] [PubMed]

20. Assiri, A.; Al-Tawfiq, J.A.; Al-Rabeeah, A.A.; Al-Rabiah, F.A.; Al-Hajjar, S.; Al-Barrak, A.; Flemban, H.; Al-nassir, W.N.; Balkhy, H.H.; Al-Hakeem, R.F.; et al. Epidemiological, demographic, and clinical characteristics of 47 cases of Middle East respiratory syndrome coronavirus disease from Saudi Arabia: A descriptive study. Lancet Infect. Dis. 2013, 13, 752-761. [CrossRef] 
21. Kang, C.K.; Song, K.H.; Choe, P.G.; Park, W.B.; Bang, J.H.; Kim, E.S.; Park, S.W.; Kim, H.B.; Kim, N.J.; Cho, S.I.; et al. Clinical and epidemiologic characteristics of spreaders of Middle East respiratory syndrome coronavirus during the 2015 outbreak in Korea. J. Korean Med. Sci. 2017, 32, 744-749. [CrossRef] [PubMed]

22. Virlogeux, V.; Park, M.; Wu, J.T.; Cowling, B.J. Association between severity of MERS-CoV infection and incubation period. Emerg. Infect. Dis. 2016, 22, 526-528. [CrossRef] [PubMed]

23. Al-Hameed, F.; Wahla, A.S.; Siddiqui, S.; Ghabashi, A.; Al-Shomrani, M.; Al-Thaqafi, A.; Tashkandi, Y. Characteristics and outcomes of Middle East respiratory syndrome coronavirus patients admitted to an intensive care unit in Jeddah, Saudi Arabia. J. Intensive Care Med. 2015. [CrossRef] [PubMed]

24. Arabi, Y.M.; Arifi, A.A.; Balkhy, H.H.; Najm, H.; Aldawood, A.S.; Ghabashi, A.; Hawa, H.; Alothman, A.; Khaldi, A.; Al Raiy, B. Clinical course and outcomes of critically Ill patients with Middle East respiratory syndrome coronavirus infection. Ann. Intern. Med. 2014, 160, 389-397. [CrossRef] [PubMed]

25. Thabet, F.; Chehab, M.; Bafaqih, H.; AlMohaimeed, S. Middle East respiratory syndrome coronavirus in children. Saudi Med. J. 2015, 36, 484-486. [CrossRef] [PubMed]

26. Alraddadi, B.M.; Watson, J.T.; Almarashi, G.R.A.; Turkistani, A.; Sadran, M.; Housa, A.; Almazroa, M.A.; Alraihan, N.; Banjar, A.; Albalawi, E.; et al. Risk factors for primary Middle East respiratory syndrome coronavirus illness in humans, Saudi Arabia, 2014. Emerg. Infect. Dis. 2016, 22. [CrossRef] [PubMed]

27. Badawi, A.; Ryoo, S.G. Prevalence of comorbidities in the Middle East respiratory syndrome coronavirus (MERS-CoV): A systematic review and meta-analysis. Int. J. Infect. Dis. 2016, 49, 129-133. [CrossRef] [PubMed]

28. Al-Abdallat, M.M.; Payne, D.C.; Alqasrawi, S.; Rha, B.; Tohme, R.A.; Abedi, G.R.; Al, N.M.; Iblan, I.; Jarour, N.; Farag, N.H.; et al. Hospital-associated outbreak of Middle East Respiratory syndrome coronavirus: A serologic, epidemiologic, and clinical description. Clin. Infect. Dis. 2014, 59, 1225-1233. [CrossRef] [PubMed]

29. Memish, Z.A. Invited Editorial: MERS-CoV An emerging viral zoonotic disease: Three years after and counting. Recent Pat. Anti Infect. Drug Discov. 2014, 9, 159-160. [CrossRef]

30. Alsaad, K.O.; Hajeer, A.H.; Al Balwi, M.; Al Moaiqel, M.; Al Oudah, N.; Al Ajlan, A.; AlJohani, S.; Alsolamy, S.; Gmati, G.E.; Balkhy, H.; et al. Histopathology of Middle East respiratory syndrome coronovirus (MERS-CoV) infection-Clinicopathological and ultrastructural study. Histopathology 2017. [CrossRef] [PubMed]

31. Kim, J.E.; Heo, J.H.; Kim, H.O.; Song, S.H.; Park, S.S.; Park, T.H.; Ahn, J.Y.; Kim, M.K.; Choi, J.P. Neurological complications during treatment of Middle East respiratory syndrome. J. Clin. Neurol. 2017, 13, 227-233. [CrossRef] [PubMed]

32. Mizumoto, K.; Saitoh, M.; Chowell, G.; Miyamatsu, Y.; Nishiura, H. Estimating the risk of Middle East respiratory syndrome (MERS) death during the course of the outbreak in the Republic of Korea, 2015. Int. J. Infect. Dis. 2015. [CrossRef] [PubMed]

33. Matsuyama, R.; Nishiura, H.; Kutsuna, S.; Hayakawa, K.; Ohmagari, N. Clinical determinants of the severity of Middle East respiratory syndrome (MERS): A systematic review and meta-analysis. BMC Public Health. 2016, 16, 1203. [CrossRef] [PubMed]

34. Scientific Advisory Council MoH. Saudi Arabia, Infection prevention/control and management guidelines for patients with Middle East Respitaory Syndrome Coronavius (MERS-CoV) infection. 2014. Available online: http://www.moh.gov.sa/en/CCC/StaffRegulations/Corona/Documents/ GuidelinesforCoronaPatients.pdf (accessed on 27 April 2015).

35. Hemida, M.G.; Perera, R.A.; Al Jassim, R.A.; Kayali, G.; Siu, L.Y.; Wang, P.; Chu, K.W.; Perlman, S.; Ali, M.A.; Alnaeem, A.; et al. Seroepidemiology of Middle East respiratory syndrome (MERS) coronavirus in Saudi Arabia and Australia and characterisation of assay specificity. Eur. Commun. Dis. Bull. 2014, 19, 20828.

36. Muth, D.; Corman, V.M.; Meyer, B.; Assiri, A.; Al-Masri, M.; Farah, M.; Steinhagen, K.; Lattwein, E.; Al-Tawfiq, J.A.; Albarrak, A.; et al. Infectious Middle East Respiratory syndrome coronavirus excretion and serotype variability based on live virus isolates from patients in Saudi Arabia. J. Clin. Microbiol. 2015, 53, 2951-2955. [CrossRef] [PubMed]

37. Choe, P.G.; Perera, R.; Park, W.B.; Song, K.H.; Bang, J.H.; Kim, E.S.; Kim, H.B.; Ko, L.W.R.; Park, S.W.; Kim, N.J.; et al. MERS-CoV Antibody responses 1 year after symptom onset, South Korea, 2015. Emerg. Infect. Dis. 2017, 23, 1079-1084. [CrossRef] [PubMed] 
38. Alshukairi, A.N.; Khalid, I.; Ahmed, W.A.; Dada, A.M.; Bayumi, D.T.; Malic, L.S.; Althawadi, S.; Ignacio, K.; Alsalmi, H.S.; Al-Abdely, H.M.; et al. Antibody response and disease severity in healthcare worker MERS survivors. Emerg. Infect. Dis. 2016, 22. [CrossRef] [PubMed]

39. Arabi, Y.M.; Hajeer, A.H.; Luke, T.; Raviprakash, K.; Balkhy, H.; Johani, S.; Al-Dawood, A.; Al-Qahtani, S.; Al-Omari, A.; Al-Hameed, F.; et al. Feasibility of using convalescent plasma immunotherapy for MERS-CoV infection, Saudi Arabia. Emerg. Infect. Dis. 2016, 22, 1554-1561. [CrossRef] [PubMed]

40. Ko, J.H.; Muller, M.A.; Seok, H.; Park, G.E.; Lee, J.Y.; Cho, S.Y.; Ha, Y.E.; Baek, J.Y.; Kim, S.H.; Kang, J.M.; et al. Serologic responses of 42 MERS-coronavirus-infected patients according to the disease severity. Diagn. Microbiol. Infect. Dis. 2017, 89, 106-111. [CrossRef] [PubMed]

41. Corman, V.M.; Albarrak, A.M.; Omrani, A.S.; Albarrak, M.M.; Farah, M.E.; Almasri, M.; Muth, D.; Sieberg, A.; Meyer, B.; Assiri, A.M.; et al. Viral shedding and antibody response in 37 patients with Middle East respiratory syndrome coronavirus infection. Clin. Infect. Dis. 2016, 62, 477-483. [CrossRef] [PubMed]

42. Payne, D.C.; Iblan, I.; Rha, B.; Alqasrawi, S.; Haddadin, A.; Al Nsour, M.; Alsanouri, T.; Ali, S.S.; Harcourt, J.; Miao, C.; et al. Persistence of antibodies against Middle East respiratory syndrome coronavirus. Emerg. Infect. Dis. 2016, 22, 1824-1826. [CrossRef] [PubMed]

43. Zhao, J.; Alshukairi, A.N.; Baharoon, S.A.; Ahmed, W.A.; Bokhari, A.A.; Nehdi, A.M.; Laygah, L.A.; Alghamdi, M.G.; Al Gethamy, M.M.; Dada, A.M.; et al. Recovery from the Middle East respiratory syndrome is associated with antibody and T-cell responses. Sci. Immunol. 2017, 2, 14. [CrossRef] [PubMed]

44. Corman, V.M.; Muller, M.A.; Costabel, U.; Timm, J.; Binger, T.; Meyer, B.; Kreher, P.; Lattwein, E.; Eschbach-Bludau, M.; Nitsche, A.; et al. Assays for laboratory confirmation of novel human coronavirus (hCoV-EMC) infections. Eurosurveillance 2012, 17, 49. [CrossRef]

45. Xiao, S.; Li, Y.; Sung, M.; Wei, J.; Yang, Z. A study of the probable transmission routes of MERS-CoV during the first hospital outbreak in the Republic of Korea. Indoor Air 2017. [CrossRef] [PubMed]

46. Mackay, I.M.; Arden, K.E. MERS coronavirus: Diagnostics, epidemiology and transmission. Virol. J. 2015, 12, 222. [CrossRef] [PubMed]

47. Organization, W.H. Laboratory Testing for Middle East Respiratory Syndrome Coronavirus I Interim Guidance: World Health Organization. 2015. Available online: http://www.who.int/csr/disease/ coronavirus_infections/mers-laboratory-testing/en/ (accessed on 4 September 2015).

48. Chan, J.F.; Sridhar, S.; Yip, C.C.; Lau, S.K.; Woo, P.C. The role of laboratory diagnostics in emerging viral infections: The example of the Middle East respiratory syndrome epidemic. J. Microbiol. 2017, 55, 172-182. [CrossRef] [PubMed]

49. Lessler, J.; Salje, H.; van Kerkhove, M.D.; Ferguson, N.M.; Cauchemez, S.; Rodriquez-Barraquer, I.; Hakeem, R.; Jombart, T.; Aguas, R.; Al-Barrak, A.; et al. Estimating the severity and subclinical burden of Middle East respiratory syndrome coronavirus infection in the Kingdom of Saudi Arabia. Am. J. Epidemiol. 2016, 183, 657-663. [CrossRef] [PubMed]

50. Drosten, C.; Meyer, B.; Muller, M.A.; Corman, V.M.; Al-Masri, M.; Hossain, R.; Madani, H.; Sieberg, A.; Bosch, B.J.; Lattwein, E.; et al. Transmission of MERS-coronavirus in household contacts. N. Engl. J. Med. 2014, 371, 828-835. [CrossRef] [PubMed]

51. Oboho, I.K.; Tomczyk, S.M.; Al-Asmari, A.M.; Banjar, A.A.; Al-Mugti, H.; Aloraini, M.S.; Alkhaldi, K.Z.; Almohammadi, E.L.; Alraddadi, B.M.; Gerber, S.I.; et al. 2014 MERS-CoV outbreak in Jeddah-A link to health care facilities. N. Engl. J. Med. 2015, 372, 846-854. [CrossRef] [PubMed]

52. Ali, M.A.; Shehata, M.M.; Gomaa, M.R.; Kandeil, A.; El-Shesheny, R.; Kayed, A.S.; El-Taweel, A.N.; Atea, M.; Hassan, N.; Bagato, O.; et al. Systematic, active surveillance for Middle East respiratory syndrome coronavirus in camels in Egypt. Emerg. Microbes Infect. 2017, 6, e1. [CrossRef] [PubMed]

53. Miguel, E.; Chevalier, V.; Ayelet, G.; Ben Bencheikh, M.N.; Boussini, H.; Chu, D.K.; El Berbri, I.; Fassi-Fihri, O.; Faye, B.; Fekadu, G.; et al. Risk factors for MERS coronavirus infection in dromedary camels in Burkina Faso, Ethiopia, and Morocco, 2015. Euro Surveill. 2017, 22. [CrossRef] [PubMed]

54. Saqib, M.; Sieberg, A.; Hussain, M.H.; Mansoor, M.K.; Zohaib, A.; Lattwein, E.; Muller, M.A.; Drosten, C.; Corman, V.M. Serologic evidence for MERS-CoV infection in Dromedary Camels, Punjab, Pakistan, 2012-2015. Emerg. Infect. Dis. 2017, 23, 550-551. [CrossRef] [PubMed]

55. Younan, M.; Bornstein, S.; Gluecks, I.V. MERS and the dromedary camel trade between Africa and the Middle East. Trop. Anim. Health Prod. 2016, 48, 1277-1282. [CrossRef] [PubMed] 
56. Widagdo, W.; Okba, N.M.A.; Stalin Raj, V.; Haagmans, B.L. MERS-coronavirus: From discovery to intervention. One Health 2017, 3, 11-16. [CrossRef] [PubMed]

57. De Wit, E.; Feldmann, F.; Horne, E.; Martellaro, C.; Haddock, E.; Bushmaker, T.; Rosenke, K.; Okumura, A.; Rosenke, R.; Saturday, G.; et al. Domestic pig unlikely reservoir for MERS-CoV. Emerg. Infect. Dis. 2017, 23, 985-988. [CrossRef] [PubMed]

58. Vergara-Alert, J.; van den Brand, J.M.; Widagdo, W.; Munoz, M.; Raj, S.; Schipper, D.; Solanes, D.; Cordon, I.; Bensaid, A.; Haagmans, B.L.; et al. Livestock susceptibility to infection with Middle East respiratory syndrome coronavirus. Emerg. Infect. Dis. 2017, 23, 232-240. [CrossRef] [PubMed]

59. Al-Tawfiq, J.A.; Memish, Z.A. Managing MERS-CoV in the healthcare setting. Hosp. Pract. 2015, 43, $158-163$. [CrossRef] [PubMed]

60. Chu, D.K.W.; Poon, L.L.M.; Gomaa, M.R.; Shehata, M.M.; Perera, R.A.P.M.; Zeid, D.A.; El Rifay, A.S.; Siu, L.Y.; Guan, Y.; Webby, R.J.; et al. MERS coronaviruses in dromedary camels, Egypt. Emerg. Infect. Dis. 2014, 20, 1049. [CrossRef] [PubMed]

61. Millet, J.K.; Goldstein, M.E.; Labitt, R.N.; Hsu, H.L.; Daniel, S.; Whittaker, G.R. A camel-derived MERS-CoV with a variant spike protein cleavage site and distinct fusion activation properties. Emerg. Microbes Infect. 2016, 5, e126. [CrossRef] [PubMed]

62. Adams, M.J.; Lefkowitz, E.J.; King, A.M.; Harrach, B.; Harrison, R.L.; Knowles, N.J.; Kropinski, A.M.; Krupovic, M.; Kuhn, J.H.; Mushegian, A.R.; et al. Ratification vote on taxonomic proposals to the International Committee on Taxonomy of Viruses. Arch. Virol. 2016, 161, 2921-2949. [CrossRef] [PubMed]

63. Yang, L.; Wu, Z.; Ren, X.; Yang, F.; Zhang, J.; He, G.; Dong, J.; Sun, L.; Zhu, Y.; Zhang, S.; et al. MERS-related betacoronavirus in Vespertilio superans bats, China. Emerg. Infect. Dis. 2014, 20, 1260-1262. [CrossRef] [PubMed]

64. Anthony, S.J.; Gilardi, K.; Menachery, V.D.; Goldstein, T.; Ssebide, B.; Mbabazi, R.; Navarrete-Macias, I.; Liang, E.; Wells, H.; Hicks, A.; et al. Further evidence for bats as the evolutionary source of Middle East Respiratory syndrome coronavirus. MBio 2017, 8. [CrossRef] [PubMed]

65. Command \& Control Center MoH. Kingdom of Saudi Arabia. MERS-CoV Statistics: Command \& Control Center, Ministry of Health, Kingdom of Saudi Arabia. Available online: https:/ / www.moh.gov.sa/en/CCC/ pressreleases/pages/default.aspx (accessed on 15 October 2017).

66. Sun, Y.; Zhang, H.; Shi, J.; Zhang, Z.; Gong, R. Identification of a novel inhibitor against Middle East respiratory syndrome coronavirus. Viruses 2017, 9, 255. [CrossRef] [PubMed]

67. Van, D.N.; Bushmaker, T.; Munster, V.J. Stability of Middle East respiratory syndrome coronavirus (MERS-CoV) under different environmental conditions. Eurosurveillance 2013, 18, 20590.

68. Kim, S.H.; Chang, S.Y.; Sung, M.; Park, J.H.; Bin Kim, H.; Lee, H.; Choi, J.P.; Choi, W.S.; Min, J.Y. Extensive viable Middle East respiratory syndrome (MERS) coronavirus contamination in air and surrounding environment in MERS isolation wards. Clin. Infect. Dis. 2016, 63, 363-369. [CrossRef] [PubMed]

69. Van Kerkhove, M.D.; Peiris, M.J.; Malik, M.R.; Ben Embarek, P. Interpreting results from environmental contamination studies of Middle East respiratory syndrome coronavirus. Clin. Infect. Dis. 2016, 63, 1142. [CrossRef] [PubMed]

70. Khan, R.M.; Al-Dorzi, H.M.; Al Johani, S.; Balkhy, H.H.; Alenazi, T.H.; Baharoon, S.; Arabi, Y.M. Middle East respiratory syndrome coronavirus on inanimate surfaces: A risk for health care transmission. Am. J. Infect. Control 2016, 44, 1387-1389. [CrossRef] [PubMed]

71. Song, J.Y.; Cheong, H.J.; Choi, M.J.; Jeon, J.H.; Kang, S.H.; Jeong, E.J.; Yoon, J.G.; Lee, S.N.; Kim, S.R.; Noh, J.Y.; et al. Viral shedding and environmental cleaning in Middle East respiratory syndrome coronavirus infection. Infect. Chemother. 2015, 47, 252-255. [CrossRef] [PubMed]

72. Leclercq, I.; Batejat, C.; Burguiere, A.M.; Manuguerra, J.C. Heat inactivation of the Middle East respiratory syndrome coronavirus. Influenza Other Respir. Viruses 2014, 8, 585-586. [CrossRef] [PubMed]

73. Eggers, M.; Eickmann, M.; Zorn, J. Rapid and effective virucidal activity of povidone-iodine products against Middle East respiratory syndrome coronavirus (MERS-CoV) and modified vaccinia virus ankara (MVA). Infect. Dis. Ther. 2015, 4, 491-501. [CrossRef] [PubMed]

74. Hemida, M.G.; Alnaeem, A.; Chu, D.K.; Perera, R.A.; Chan, S.M.; Almathen, F.; Yau, E.; Ng, B.C.; Webby, R.J.; Poon, L.L.; et al. Longitudinal study of Middle East respiratory syndrome coronavirus infection in dromedary camel herds in Saudi Arabia, 2014-2015. Emerg. Microbes Infect. 2017, 6, e56. [CrossRef] [PubMed] 
75. Muller, M.A.; Corman, V.M.; Jores, J.; Meyer, B.; Younan, M.; Liljander, A.; Bosch, B.J.; Lattwein, E.; Hilali, M.; Musa, B.E.; et al. MERS coronavirus neutralizing antibodies in camels, Eastern Africa, 1983-1997. Emerg. Infect. Dis. 2014, 20, 2093-2095. [CrossRef] [PubMed]

76. Reusken, C.B.; Farag, E.A.; Jonges, M.; Godeke, G.J.; El-Sayed, A.M.; Pas, S.D.; Raj, V.S.; Mohran, K.A.; Moussa, H.A.; Ghobashy, H.; et al. Middle East respiratory syndrome coronavirus (MERS-CoV) RNA and neutralising antibodies in milk collected according to local customs from dromedary camels, Qatar, April 2014. Eurosurveillance 2014, 19, 23. [CrossRef]

77. Van Doremalen, N.; Bushmaker, T.; Karesh, W.B.; Munster, V.J. Stability of Middle East respiratory syndrome coronavirus in milk. Emerg. Infect. Dis. 2014, 20, 1263-1264. [CrossRef] [PubMed]

78. Gossner, C.; Danielson, N.; Gervelmeyer, A.; Berthe, F.; Faye, B.; Kaasik, A.K.; Adlhoch, C.; Zeller, H.; Penttinen, P.; Coulombier, D. Human-dromedary camel interactions and the risk of acquiring zoonotic Middle East respiratory syndrome coronavirus infection. Zoonoses Public Health 2016, 63, 1-9. [CrossRef] [PubMed]

79. Poletto, C.; Boelle, P.Y.; Colizza, V. Risk of MERS importation and onward transmission: A systematic review and analysis of cases reported to WHO. BMC Infect. Dis. 2016, 16, 448. [CrossRef] [PubMed]

80. Choi, S.; Jung, E.; Choi, B.Y.; Hur, Y.J.; Ki, M. High reproduction number of Middle East respiratory syndrome coronavirus in nosocomial outbreaks: Mathematical modelling in Saudi Arabia and South Korea. J. Hosp. Infect. 2017. [CrossRef] [PubMed]

81. Korea Centers for Disease Control and Prevention. Middle East Respiratory Syndrome Coronavirus Outbreak in the Republic of Korea, 2015. Osong Public Health Res. Perspect. 2015, 6, 269-278. [CrossRef]

82. Wong, G.; Liu, W.; Liu, Y.; Zhou, B.; Bi, Y.; Gao, G.F. MERS, SARS, and Ebola: The Role of Super-Spreaders in Infectious Disease. Cell Host Microbe. 2015, 18, 398-401. [CrossRef] [PubMed]

83. Stein, R.A. Super-spreaders in infectious diseases. Int. J. Infect. Dis. 2011, 15, e510-e513. [CrossRef] [PubMed]

84. Al-Gethamy, M.; Corman, V.M.; Hussain, R.; Al-Tawfiq, J.A.; Drosten, C.; Memish, Z.A. A case of long-term excretion and subclinical infection with Middle East respiratory syndrome coronavirus in a healthcare worker. Clin. Infect. Dis. 2015, 60, 973-974. [CrossRef] [PubMed]

85. Moon, S.Y.; Son, J.S. Infectivity of an asymptomatic patient with Middle East respiratory syndrome coronavirus infection. Clin. Infect. Dis. 2017, 64, 1457-1458. [CrossRef] [PubMed]

86. Al-Tawfiq, J.A.; Zumla, A.; Memish, Z.A. Respiratory tract infections during the annual Hajj: Potential risks and mitigation strategies. Curr. Opin. Pulm. Med. 2013, 19, 192-197. [CrossRef] [PubMed]

87. Prevention CfDCa. Interim infection prevention and control recommendations for hospitalized patients with Middle East respiratory syndrome coronavirus (MERS-CoV). 2015. Available online: https:/ / www.cdc.gov/ coronavirus/mers/infection-prevention-control.html (accessed on 15 October 2017).

88. Okba, N.M.; Raj, V.S.; Haagmans, B.L. Middle East respiratory syndrome coronavirus vaccines: Current status and novel approaches. Curr. Opin. Virol. 2017, 23, 49-58. [CrossRef] [PubMed]

89. Zumla, A.; Chan, J.F.; Azhar, E.I.; Hui, D.S.; Yuen, K.Y. Coronaviruses-Drug discovery and therapeutic options. Nat. Rev. Drug Discov. 2016, 15, 327-347. [CrossRef] [PubMed]

90. Goldstein, S.A.; Weiss, S.R. Origins and pathogenesis of Middle East respiratory syndrome-associated coronavirus: Recent advances. F1000Research 2017, 6, 1628. [CrossRef] [PubMed]

91. Rabaan, A.A.; Alahmed, S.H.; Bazzi, A.M.; Alhani, H.M. A review of candidate therapies for Middle East respiratory syndrome from a molecular perspective. J. Med. Microbiol. 2017. [CrossRef] [PubMed]

92. Rabaan, A.A. Middle East respiratory syndrome coronavirus: Five years later. Expert Rev. Respir. Med. 2017, 11, 901-912. [CrossRef] [PubMed]

93. Lan, J.; Deng, Y.; Chen, H.; Lu, G.; Wang, W.; Guo, X.; Lu, Z.; Gao, G.F.; Tan, W. Tailoring subunit vaccine immunity with adjuvant combinations and delivery routes using the Middle East respiratory coronavirus (MERS-CoV) receptor-binding domain as an antigen. PLoS ONE 2014, 9, e112602. [CrossRef] [PubMed]

94. Choi, J.; Kim, M.G.; Oh, Y.K.; Kim, Y.B. Progress of Middle East respiratory syndrome coronavirus vaccines: A patent review. Expert Opin. Ther. Pat. 2017, 27, 721-731. [CrossRef] [PubMed]

95. Crameri, G.; Durr, P.A.; Barr, J.; Yu, M.; Graham, K.; Williams, O.J.; Kayali, G.; Smith, D.; Peiris, M.; Mackenzie, J.S.; et al. Absence of MERS-CoV antibodies in feral camels in Australia: Implications for the pathogen's origin and spread. One Health 2015. [CrossRef] [PubMed] 
96. Volz, A.; Kupke, A.; Song, F.; Jany, S.; Fux, R.; Shams-Eldin, H.; Schmidt, J.; Becker, C.; Eickmann, M.; Becker, S.; et al. Protective efficacy of recombinant modified vaccinia virus ankara delivering Middle East respiratory syndrome coronavirus spike glycoprotein. J. Virol. 2015, 89, 8651-8656. [CrossRef] [PubMed]

97. Song, F.; Fux, R.; Provacia, L.B.; Volz, A.; Eickmann, M.; Becker, S.; Osterhaus, A.D.; Haagmans, B.L.; Sutter, G. Middle East respiratory syndrome coronavirus spike protein delivered by modified vaccinia virus Ankara efficiently induces virus-neutralizing antibodies. J. Virol. 2013, 87, 11950-11954. [CrossRef] [PubMed]

98. Drexler, J.F.; Luna, L.K.; Stocker, A.; Almeida, P.S.; Ribeiro, T.C.; Petersen, N.; Herzog, P.; Pedroso, C.; Huppertz, H.I.; Ribeiro, H.C., Jr.; et al. Circulation of 3 lineages of a novel Saffold cardiovirus in humans. Emerg. Infect. Dis. 2008, 14, 1398-1405. [CrossRef] [PubMed]

99. Alharbi, N.K.; Padron-Regalado, E.; Thompson, C.P.; Kupke, A.; Wells, D.; Sloan, M.A.; Grehan, K.; Temperton, N.; Lambe, T.; Warimwe, G.; et al. ChAdOx1 and MVA based vaccine candidates against MERS-CoV elicit neutralising antibodies and cellular immune responses in mice. Vaccine 2017, 35, 3780-3788. [CrossRef] [PubMed]

100. Malczyk, A.H.; Kupke, A.; Prufer, S.; Scheuplein, V.A.; Hutzler, S.; Kreuz, D.; Beissert, T.; Bauer, S.; Hubich-Rau, S.; Tondera, C.; et al. A highly immunogenic and protective Middle East respiratory syndrome coronavirus vaccine based on a recombinant measles virus vaccine platform. J. Virol. 2015, 89, 11654-11667. [CrossRef] [PubMed]

101. Guo, X.; Deng, Y.; Chen, H.; Lan, J.; Wang, W.; Zou, X.; Hung, T.; Lu, Z.; Tan, W. Systemic and mucosal immunity in mice elicited by a single immunization with human adenovirus type 5 or 41 vector-based vaccines carrying the spike protein of Middle East respiratory syndrome coronavirus. Immunology 2015, 145, 476-484. [CrossRef] [PubMed]

102. Coleman, C.M.; Liu, Y.V.; Mu, H.; Taylor, J.K.; Massare, M.; Flyer, D.C.; Smith, G.E.; Frieman, M.B. Purified coronavirus spike protein nanoparticles induce coronavirus neutralizing antibodies in mice. Vaccine 2014, 32, 3169-3174. [CrossRef] [PubMed]

103. Almazan, F.; DeDiego, M.L.; Sola, I.; Zuniga, S.; Nieto-Torres, J.L.; Marquez-Jurado, S.; Andres, G.; Enjuanes, L. Engineering a replication-competent, propagation-defective Middle East respiratory syndrome coronavirus as a vaccine candidate. MBio 2013, 4, e00650-13. [CrossRef] [PubMed]

104. Haagmans, B.L.; van den Brand, J.M.; Raj, V.S.; Volz, A.; Wohlsein, P.; Smits, S.L.; Schipper, D.; Bestebroer, T.M.; Okba, N.; Fux, R.; et al. An orthopoxvirus-based vaccine reduces virus excretion after MERS-CoV infection in dromedary camels. Science 2016, 351, 77-81. [CrossRef] [PubMed]

105. Alharbi, N.K. Vaccines against Middle East respiratory syndrome coronavirus for humans and camels. Rev. Med. Virol. 2017, 27. [CrossRef] [PubMed]

106. Reusken, C.B.; Farag, E.A.; Haagmans, B.L.; Mohran, K.A.; Godeke, G.J.; Raj, S.; Alhajri, F.; Al-Marri, S.A.; Al-Romaihi, H.E.; Al-Thani, M.; et al. Occupational exposure to dromedaries and risk for MERS-CoV infection, Qatar, 2013-2014. Emerg. Infect. Dis. 2015, 21, 1422-1425. [CrossRef] [PubMed]

107. Corti, D.; Zhao, J.; Pedotti, M.; Simonelli, L.; Agnihothram, S.; Fett, C.; Fernandez-Rodriguez, B.; Foglierini, M.; Agatic, G.; Vanzetta, F.; et al. Prophylactic and postexposure efficacy of a potent human monoclonal antibody against MERS coronavirus. Proc. Natl. Acad. Sci. USA 2015, 112, 10473-10478. [CrossRef] [PubMed]

108. Tang, X.C.; Agnihothram, S.S.; Jiao, Y.; Stanhope, J.; Graham, R.L.; Peterson, E.C.; Avnir, Y.; Tallarico, A.S.; Sheehan, J.; Zhu, Q.; et al. Identification of human neutralizing antibodies against MERS-CoV and their role in virus adaptive evolution. Proc. Natl. Acad. Sci. USA 2014, 111, E2018-E2026. [CrossRef] [PubMed]

109. Ying, T.; Du, L.; Ju, T.W.; Prabakaran, P.; Lau, C.C.; Lu, L.; Liu, Q.; Wang, L.; Feng, Y.; Wang, Y.; et al. Exceptionally potent neutralization of Middle East respiratory syndrome coronavirus by human monoclonal antibodies. J. Virol. 2014, 88, 7796-7805. [CrossRef] [PubMed]

110. Luke, T.; Wu, H.; Zhao, J.; Channappanavar, R.; Coleman, C.M.; Jiao, J.A.; Matsushita, H.; Liu, Y.; Postnikova, E.N.; Ork, B.L.; et al. Human polyclonal immunoglobulin G from transchromosomic bovines inhibits MERS-CoV in vivo. Sci. Transl. Med. 2016, 8, 326ra21. [CrossRef] [PubMed]

111. Falzarano, D.; de, W.E.; Rasmussen, A.L.; Feldmann, F.; Okumura, A.; Scott, D.P.; Brining, D.; Bushmaker, T.; Martellaro, C.; Baseler, L.; et al. Treatment with interferon- $\alpha 2 b$ and ribavirin improves outcome in MERS-CoV-infected rhesus macaques. Nat. Med. 2013, 19, 1313-1317. [CrossRef] [PubMed] 
112. Chan, J.F.; Yao, Y.; Yeung, M.L.; Deng, W.; Bao, L.; Jia, L.; Li, F.; Xiao, C.; Gao, H.; Yu, P.; et al. Treatment with lopinavir/ritonavir or interferon- $\beta 1 \mathrm{~b}$ improves outcome of MERS-CoV infection in a nonhuman primate model of common marmoset. J. Infect. Dis. 2015, 212, 1904-1913. [CrossRef] [PubMed]

113. Mo, Y.; Fisher, D. A review of treatment modalities for Middle East respiratory syndrome. J. Antimicrob. Chemother. 2016, 71, 3340-3350. [CrossRef] [PubMed]

114. Dyall, J.; Coleman, C.M.; Hart, B.J.; Venkataraman, T.; Holbrook, M.R.; Kindrachuk, J.; Johnson, R.F.; Olinger, G.G., Jr.; Jahrling, P.B.; Laidlaw, M.; et al. Repurposing of clinically developed drugs for treatment of Middle East respiratory coronavirus infection. Antimicrob. Agents Chemother. 2014, 58, 4885-4893. [CrossRef] [PubMed]

115. Sheahan, T.P.; Sims, A.C.; Graham, R.L.; Menachery, V.D.; Gralinski, L.E.; Case, J.B.; Leist, S.R.; Pyrc, K.; Feng, J.Y.; Trantcheva, I.; et al. Broad-spectrum antiviral GS-5734 inhibits both epidemic and zoonotic coronaviruses. Sci. Transl. Med. 2017, 9. [CrossRef] [PubMed]

116. Cheung, N.N.; Lai, K.K.; Dai, J.; Kok, K.H.; Chen, H.; Chan, K.H.; Yuen, K.Y.; Kao, R.Y.T. Broad-spectrum inhibition of common respiratory RNA viruses by a pyrimidine synthesis inhibitor with involvement of the host antiviral response. J. Gen. Virol. 2017, 98, 946-954. [CrossRef] [PubMed]

117. Mustafa, S.; Balkhy, H.; Gabere, M.N. Current treatment options and the role of peptides as potential therapeutic components for Middle East respiratory syndrome (MERS): A review. J. Infect. Public Health 2017. [CrossRef] [PubMed]

(C) 2017 by the authors. Licensee MDPI, Basel, Switzerland. This article is an open access article distributed under the terms and conditions of the Creative Commons Attribution (CC BY) license (http:/ / creativecommons.org/licenses/by/4.0/). 